not, however, expect that it will appeal to the generation now in active business life, which has grown up since the war for the Union, as it does to the comparatively few who still live as survivors of the times when most of the money in circulation was of doubtful value. But if there is one matter, aside from the record of our soldiers in the civil war, in which those Iowans who are up in the sixties and seventies feel an exalted pride it is in the good Iowa money which in 1858 succeeded a flood of trash.

The record which Maj. Sherman makes for the directors of the State Bank is an enviable one. They entered upon their new and, for the greater part, untried duties with a firm determination that their work should be in all respects substantial and honorable. From the iron rules which they laid down for the guidance of the central organization and the individual branches there was never a shadow of turning. The action of each local bank was closely watched, and whenever anything unlike good banking was detected, an investigation was immediately ordered, and whatever was amiss was at once corrected. This story will be new to most readers, but none the less will it long be read with deep interest by the people of Iowa. While none of the worthless currency of the preceding period originated in our State, it had become a favorite field in which to circulate all sorts of doubtful stuff from other sections. But the first step taken by our legislature, and so wisely carried out by the old State Bank, gave Iowa a proud fnancial standing which has existed ever since.

\title{
GRAVES OF REVOLUTIONARY SOLDIERS IN IOWA.
}

At least five soldiers who fought in the Revolutionary War died and were buried in this State. Possibly there may have been others, but our knowledge only extends to the five. Their names were Timothy Brown, Charles Shepherd, William Blair, George Perkins and John Osborn.

Timothy Brown enlisted in April, 1780, and served three years as a private, a portion of the time under Capt! Richard Cox, in a regiment com- 
manded by Col. Charles Dayton. His next company commander was Capt. Alex. Mitchell, and his next colonel was Matthias Ogden. He participated. in the battles of Monmouth, Springfield and Yorktown, witnessing the surreuder of Lord Cornwallis. He was discharged at Little Britain, N. Y. While resiaing in Franklin county, Ind., he was granted a pension June 2, 1818. He had previously received a badge of merit for three years of faithful service. It was stated in The Western American, of Keosauqua, Iowa. June 17, 1852, that Timothy Brown, a revolutionary soldier, had died on. the 30th of the previous month, in Washington county, Iowa, at the advanced age of ninety-one years. But investigations kindly undertaken by Mr.H.A. Burrell, of The Washington Press, have failed to identify the place where Timothy Brown was buried. Of the facts that he ended his days in that county, and was buried somewhere within its borders, there would seem to be no doubt. The place of his interment may some day be identified.

George Perkins was born in Liberty county, South Carolina, March 22, 1754. He enlisted no less than nine times from 1776 to 1780 , for short. periods of service, varying from one month to five. He served as a private under Captains Gregg, LeBash, Evans, Cade, Robinson, Pearson and Whittington, and one other whose name is not given. He served in eight different regimental commands, but did not participate in any battle. He enlisted somewhere in South Carolina. His application for a pension was. dated March 11, 1843, and was granted. He died November 15, 1840, and according to information secured by the "Daughters of the American Revolution," was buried near Primrose, Lee county, on the farm of the late John McGreer. His age was 88 years and 8 months. The desultory character of his service probably arose from the fact that he served under Gen. Francis Marion.

William Blair was born in Lancaster county, Pennsylvania, in 1760 . He resided in Cumberland county, Pennsylvania, at the date of his first enlistment. He is credited with service as a private under three different enlistments, which were for two, five and seven months, from May, 1778, to June, 1780. His ceptains under these three enlistments were George Ball, Henry Dougherty and Gilbert McCoy. He was once in the command of Gen. John Sullivan, who so successfully fought the Indians, and also served under a Col. Clark. Before he had attained his majority he served two months (in 1778) as his father's substitute, and was in several campaigns against the Tories, British and Indians. He was disabled at the battle of Chemung, leaving the service for a time, but later rejoined and was mustered out with his regiment. After many experiences in pioneer life, he came to Round Prairie, Kossuth county, Iowa, in 1837, where three years later, he died. Two of his sons, Thomas and David Evans Blair, settled in Iowa when this was a part of Michigan territory and were prominent in the public life of our early days. Thomas was one of the seven representatives. from Des Moines county in the first session of the Wisconsin territorial legislature, which convened at Belmont, October 25, 1836. He also served. in the second session of this body which met at Burlington, November 6 , 1837 , and in the special session which was begun at Burlington June 11, 
1838. He was also a member of the first Iowa territorial assembly which convened at Burlington, November 12, 1838. David E. Blair was elected to the Fourth Iowa territorial legislature, which met at Burlington, December 6, 1841, and to the Fifth; which convened at Iowa City, December 5, 1842. He was also chosen to the first State legislature, which convened at Iowa City, November 30, 1846. The old soldier did not asis fur a pension until he had reached his seventy-second year, when his application was granted. His grandson, Mr. M. W. Blair, is at present a resident of Kossuth, Iowa. There has been some agitation of the project to place a tablet to his memory in the Iowa Historical Building, but no action has yet been taken. During the past fow months his family representatives at Sioux City and Kossuth have erected a monument over his grave in the little cemetery three miles from Kossuth, Iowa. The following is the inscription on the stone, which is shortly to be dedicated:

William Blair,

Born Lancaster, $\mathbf{P a}, 1760$.

Died Des Moines county, Iowa, $18 \pm 0$.

A soldier of the American Revolution.

An elder in the Presbyterian church.

A pioneer in Pa., Ky., Ohio, Ind., Ill., Iowa.

Charles Shepherd served in the Fourth regiment of artillery three years and nine months. His rank was that of "matross," or gunner's assistant. The date and place of his birth are unknown. He enlisted in 1777, at York, Pennsylvania. His captain was Patrick Duffy and his colonel Thomas Proctor. He was discharged at Trenton, New Jersey, but the date is not given. While residing at Duanesville, New York, in 1818, he applied for a pension, which was granted. His age at that time was 58 years. He participated in the battles of Brandywine and Germantown. He died in 1848 , and was buried on his farm about seven miles from Rome, Iowa.

John Osborn was born April 16, 1763, in Shenandoah county, Virginia, but during the greater portion of his military service resided in Montgomery county in the same state. He enlisted in May, 1780, and served four months under his uncle, Captain Enoch Osborn, who commanded a company in the regiment of Colonel Preston of that state. This command went to Tennessee to hold in check the Shawnee and Cherokee Indians and Tories. In 1781 he served six months under the same officers at Blackmore Station, near the Tennessee mountains, for the protection of the frontier settlements. Later, he served six months as a light-horseman under Colonel William Campbell, patrolling certain portions of the state of North Carolina for the purpose of watching the Tories. He was discharged in September, 1782 , but was afterward ordered out to serve in the militia of that state. His last service was for a period of twelve months in garrison at Whitton's Station, Tennessee, in the command of Colonel Preston. After the war he resided for a time in North Carolina, thence removing to Kentucky and later to Indiana. In May, 1852, he settled in McDonough county, Illinois, where he resided but a short time until he came to Center Point, Linn county, Iowa, where he died in 1854. He was buried in the cemetery at that place. In 1894 Denison Post No. 244, G. A. R., assisted by the 
citizens of Center Point, erected a fine granite monument to his memory.

For the information contained in the above notes we are indebted to the records of the U.S. Pension Bureau and the researches of the lowa Daughters of the American Revolution.

In addition to the above, a soldier who had fought on the side of the British, died and was buried at Burlington in the autumn of 1833 . His name was Ross, but his given name or names are no longer known with certainty. Neither can the spot where he was buried be identified. "His grave," writes the Rev. Dr. William Salter, "is believed to have been in the old cemetery, (on ground given for that purpose by Major Jeremiah Smith, the first merchant here, now occupied by the Burlington Institute and High School and many dwellings." Dr. William R. Ross, the first postmaster of Burlington, and one of its earliest merchants, was his son. The aged man had previously lived in Lexington, Kentucky. He passed away a few months after reaching Burlington, and "was the first white person buried in that section of the New Purchase."

\section{THE BATTLE OF ATHENS, MO.}

Athens is a post village of Clarke county, Mo., on the west side of the Des Moines river, some twenty miles northwest of Keokuk. Croton station, Iowa, on the Chicago, Rock Island \& Pacific railway, is on the east side of the Des Moines river, about half a mile from Athens. "The battle of Athene" was an affair which occurred at that place August 4, 1861. Considered by itself alone, the event was altogether unimportant, but when it is remembered that it occurred so near the outbreak of the civil war, and that it resulted in the complete discomfiture of the Confederate forces which had started out with the intention of invading Iowa, its results were highly important. The population of southern Iowa was altogether peaceable and quiet, while there were hundreds, if not thousands, of Missourians who were ready at a moment's notice to engage in a raid into our State. In the leading article in today's Ansals, Gen. Cyrus Bussey gives a clear and succinct account of the events which preceded and led up to this affair. The article becomes all the more important from the fact that he adds several letters from the correspondence between himself and the authorities of our State. At that time he held a staff appointment under Governor Kirkwood, with authority to act upon his own discretion in any emergency which might arise. How promptly and admirably he used that discretion he clearly sets forth. Until he had made himself thoroughly understood, he was censured for interference with the plans of the State and general government, and also of Col. G. M. Dodge, who was at that time organizing the Fourth Iowa Infantry at Council Bluffs. Bat it will be seen by the letters of Governor Kirkwood, Adjutant General Baker and Judge Caleb Baldwin, that his course was heartily endorsed. In his speech before the Crocker Brigade on the 27 th of September, 1900 , which was copied into The Annals for January, 1901 (pp. 577-594), Gen. Dodge also makes mention of this action of Gen. Bussey.

As Gen. Bussey deals more particularly with events preceding the bat- 
Copyright of Annals of Iowa is the property of State of Iowa, by \& through the State Historical Society of Iowa and its content may not be copied or emailed to multiple sites or posted to a listserv without the copyright holder's express written permission. However, users may print, download, or email articles for individual use. 